\title{
Life Sentence: Mollusc Prisoner in Cretaceous Brachiopod Reconstructed in 3D. First Evidence for the Co-Existence of A Mollusc Inside a Living Animal
}

László Bujtor ( $\nabla$ bujtor.laszlo.geology@gmail.com )

University of Pecs

Philippe Andrey

University of Paris-Saclay

\section{Research Article}

Keywords: entombed fossil, peculiar non-coaction, 3D modelling, virtual shell reconstruction, Early Cretaceous, kingenoid brachiopod

Posted Date: March 24th, 2021

DOI: https://doi.org/10.21203/rs.3.rs-250566/v1

License: (c) (1) This work is licensed under a Creative Commons Attribution 4.0 International License.

Read Full License 


\section{Abstract}

A tiny shell (7 mm length) of a juvenile Mollusc (supposed gastropod) was discovered enclosed within the packstone filled shell of a terebratellidine brachiopod (Zittelina hofmanni Bujtor and Vörös, 2020) from the Lower Cretaceous Apátvarasd Limestone Formation of Zengővárkony (Mecsek Mountains, South Hungary). Serial sectioning of the brachiopod shell revealed that in addition to the brachidium, a different and unusual shelly structure was preserved inside the brachiopod shell. 2D serial sections were digitalized and fed into Free-D imaging software to generate a 3D reconstruction of the entombed fossil, which is supposed a juvenile gastropod. Consideration of the emplacement, dimensions, and orientation of the shell suggests that it entered the cavity of the living brachiopod shell as an egg or larva and was trapped. Further analysis of both fossils suggests that the two animals lived and developed beside each other for a longer period: the brachiopod crus is less developed and slightly deformed on the gastropod side with the gastropod placed parallel to the crura and the lateral wall of the brachiopod. This example suggests that shells of brachiopods may have provided sheltered microhabitats for benthic micro- and macrofossils not only after the death but even during the life of the host brachiopod. This is the first evidence from the fossil record for the co-existence of a living Mollusc inside the shell of a living brachiopod. This work illustrates how general purpose 3D modelling software initially developed in other disciplines may provide new insights in the wide field of geosciences.

\section{Introduction}

Examples of entombed fossils are scarce in the fossil record; however, they may provide significant insights into biological activities of extinct organisms. Brachiopod shells offered shelters for animals through the Phanerozoic. An exoskeleton of a trilobite (Phacops rana) from the shell of a brachiopod (Pseudoatrypa sp.) from the Middle Devonian of New York State, U.S.A. is reported ${ }^{1}$ that had occupied and lived in an empty shell of a brachiopod; the trilobite entered the shell while alive. Empty shells of orthoconic nautiloids were also used by trilobites ${ }^{2}$ that had moulted within the nautiloid body chamber using the vacant chamber of a dead nautiloid as a communal place for ecdysis (=molting). Similar shelters were reported ${ }^{3}$ from the Czech Republic; Middle Ordovician holaspid trilobites deliberately entered the restricted space under a large isolated asaphid trilobite pygidial shield to find a refuge and shared the space. Another type of sheltered preservation is known ${ }^{4}$ from the Cambrian; a tiny agnostid trilobite Peronopsisintegra entombed inside a conch of a hyolithid. An enrolled agnostid specimen preserved inside a hyolithid conch represents a new type of entombment. This fits well with earlier observations that some taxa of small agnostids voluntarily entered empty spaces inside various invertebrate skeletons lying on the bottom. Early Jurassic brachiopods with tiny ammonites inside their shells are described ${ }^{5}$ and concluded that ammonites must have been still alive while entering the empty, open brachiopod valves and the ammonites must have died later just because of the closure of the valves. Early Triassic brachiopods with entombed tiny gastropods and brachiopods are also known, ${ }^{6}$ however these entombed shells were drifted into the empty shells of their dead hosts. A hermit crab preserved inside an ammonite shell (a Jurassic Craspedites) is recently reported. ${ }^{7}$ These paguroid small 
sized crabs used the empty ammonite shells as shelters. All these findings refer to the fact that empty shells of various animals may provide shelters for other animals that were occasionally fossilized in place using empty shells of other dead animals. However, any animal remains that fossilized inside brachiopod shells are very rarely reported. In some cases microfossils are reported ${ }^{8,9,10}$ from shells: a crustacean microcoprolite fossilized in an ammonite shell, ${ }^{8}$ and foraminifers from brachiopod shells. ${ }^{9,10}$ The microfossil "entombment" in macrofossil shells cannot be considered as co-existence between the host macrofossil and the sheltering microfossil as there is no evidence for interaction between the sheltering microfossil and the hosting macrofossil (they may simply have been transported into the "host" post-mortem). From palaeobiological point of view, the co-existence of animals in the fossil record is extremely useful to understand their physiology, co-action and interaction. Special type of co-existence is parasitism. Interestingly, endoparasitism is well-known among Palaeozoic brachiopods: ${ }^{11}$ a Devonian tube-shaped parasite attached inside an atrypid brachiopod was enjoying the inhalent water current. Similar endoparasitism is known ${ }^{12}$ among spiriferid brachiopods. An ectoparasitic co-existence from the Cambrian is also known, ${ }^{13}$ where encrusting tube-dwelling organisms settled on the outer shells of their host brachiopods enjoying the inhalant water current. A rare example of co-existence between brachiopods is recognized, ${ }^{14}$ which is a real co-existence and co-action between two brachiopods in vivo. In this case the encapsulated strophomenid deviated the normal development of the crura and resulted an asymmetric brachial structure. ${ }^{14}$ Other brachiopod - brachiopod encapsulation is reported ${ }^{15}$ from the Jurassic of Romania. Other kind of co-existence from the Silurian of England is known, too. In that case an atrypid brachiopod attached to the shell of an other brachiopod (Bethia serraticulma), however this is a coexistence but without any co-actions, being epibiotic co-existence. ${ }^{16}$ These authors serially ground at $20 \mu \mathrm{m}$ intervals their specimens, digitally photographed then digitally reconstructed using custom SPIERS software suit. A surprising co-existence between living gastropods and brachiopods were reported very early ${ }^{17}$ where a brachiopod larva entered in the mantle of the gastropod, attached and attained a considerable size in this unusual environment. Reverse mode of co-existence (living gastropod in living brachiopod) is not known in bio- or geosciences yet.

Serial sectioning of brachiopods is well-established and widely used technique. ${ }^{18,19,20}$ Virtual reconstruction of internal morphology of brachiopod shells is also known. ${ }^{14,21} \mathrm{~A}$ new taxon of Silurian brachiopods is introduced based on digital reconstruction of serial sections. ${ }^{22} 3 \mathrm{D}$ modelling software is a useful tool to reconstruct from $2 \mathrm{D}$ sets of serially ground slices. ${ }^{23}$ The original aim of this study was to describe some brachiopods and investigate their internal morphology. That study resulted in some new Early Cretaceous brachiopod species, ${ }^{24}$ however during the usual serial grinding of one specimen an internally preserved shelly skeleton of an unknown Mollusc fossil was discovered. The aim of this paper is to describe and reconstruct in $3 \mathrm{D}$ a supposed gastropod that lived in a shell cavity of a living brachiopod in the Early Cretaceous.

\section{Methods}


The examined specimen is preserved as an articulated shell. Serial sections were prepared with a CutRock Croft grinding machine with slice-spacing of 50 to $200 \mu \mathrm{m}$ in the summer 2018 at the Department of Palaeontology, Hungarian Natural History Museum, Budapest. Drawings of cut surfaces were made by a Zeiss binocular microscope with a camera lucida-attachment. Orientation of the shell was prepared according to the requirements for brachiopod serial sectioning. Occasionally some colour pictures were taken by a non-professional mobile phone camera as photographic evidence to support the handmade drawings. Photographed specimen was coated with ammonium chloride. 77 serial section drawings were taken, out of which 39 are presented. A plaster cast of the serially sectioned specimen and its residual remains are housed under PAL 2019.7.1 inventory number at the palaeontological collection of the Hungarian Natural History Museum, Budapest.

Sixty-four serial section drawings were digitalized by ABBYY FineReader OCR software run on an OpticPlus 4800 scanner and stored as TIFF images. The TIFF images were imported into the Free-D software ${ }^{25}$ for $3 \mathrm{D}$ reconstruction. ${ }^{26}$ Each image was assigned a z-position corresponding to its position during the grinding process. The Free-D registration module was used to manually align the images of consecutive sections, using a combination of translations and rotations. In parallel, the Free-D automatic thresholding and contour following tool was used on each section to extract polygonal representations (sets of connected 2D vertices) of the drawings of the different structures (brachiopod crura, valves, entombed fossil). The polygonal contours were resampled uniformly to obtain a spacing of $100 \mu \mathrm{m}$ between consecutive vertices. For each structure, a triangular mesh was reconstructed by triangulating the registered contours between consecutive slices. During this process, branching structures were automatically detected and meshed. ${ }^{27}$ More complex topological changes such as the transition from closed to open structures were processed by separately reconstructing parts with different topologies followed by stitching them at additional intermediate slices using a specifically developed tool. The reconstructed 3D models were interactively displayed using the Free-D viewer. Vertex and normal smoothing were applied to enhance 3D representations and facilitate their visual interpretation. Several rounds of registration / segmentation / visualization were performed before reaching the final reconstructions.

\section{Geologic setting}

The unique Late Valanginian iron ore-related deposit (Fig. 1) at Zengővárkony (Mecsek Mountains, Hungary) was discovered in the early 1930 s based on magnetic inclination measures. The active mining period was between 1952 and 1954 and some 26,500 tons of poor-quality iron ore was excavated. ${ }^{28}$ Scientific investigation revealed microfossils from thin sections that were considered remnants of Dasycladaceae. ${ }^{29} \mathrm{~A}$ rich microfauna from the ore body is revealed its biogenic origin ${ }^{30}$ and the origin of these microfossils reporting six new crustacean microcoprolite ichnospecies and some crab antennae were.$^{31}$ Geological mapping ${ }^{32}$ reported the first macrofauna collected from the dumps of the ore mine and considered its age Upper Valanginian. New collections reported a rich brachiopod fauna ${ }^{33}$ dominated by Lacunosella hoheneggeri and Nucleata veronica. The mean dimensions of these brachiopods revealed 
a significant size increase (30-70\%) compared to populations from their type localities. This drew attention to the unique nature of this fauna. ${ }^{34}$ Oxygen and carbon stable isotope analyses did not support a seep or vent origin. ${ }^{34}$ Belemnites and dinoflagellate cysts from the basal limestone beds and its covering marl are indicated a late Valanginian - earliest Hauterivian age. ${ }^{35} \mathrm{~A}$ rich microfauna is also revealed ${ }^{36}$ and some brachiopod species were introduced: ${ }^{24}$ Dictyothyropsis vogli, Zittelina hofmanni, and Smirnovina ferraria. Serial sectioning of these brachiopods revealed a rich and unique microfauna fossilized inside the brachiopod shells. ${ }^{10}$ Additional brachiopod species were also reported ${ }^{37}$ from the fossil assemblage: there is a uniform trend and taxon-independent size increase among the brachiopods and echinoids ${ }^{10,38}$ from the unique, hydrothermally influenced fossil environment at Zengővárkony that is the first fossil member of the rare $\mathrm{SHV}^{39}$ group. ${ }^{10}$

The studied section (Fig. 2) traverses a mixed, volcano-sedimentary succession. Coordinates: $46.18545^{\circ} \mathrm{N}, 18.45299^{\circ} \mathrm{E}$. The lower part of the section represents the fully altered pillow lava and hyaloclastite version of the Mecsekjánosi Basalt Formation. Its submarine origin is revealed by vesicles in the chilled margin of the pillows. The first, red fossiliferous limestone bed typical of the Apátvarasd Limestone Formation rests concordantly upon the volcanic surface and also provided large but fragmentary and reworked pieces of phylloceratid- and lytoceratid ammonites, brachiopods, belemnite rostra, nautiloids, echinoid spines, and rare gastropods. ${ }^{8,10,24,33,34,35,36,38}$ The fossiliferous red bed is thin, never exceeds $10 \mathrm{~cm}$ in thickness. It became less fossiliferous and yellow coloured upward, then the section is terminated.

\section{Results}

Zittelina hofmanni nov. sp. was introduced from this locality. ${ }^{24}$ This kingenoid brachiopod (Fig. 3, Table 1) also revealed remarkable size increase as already indicated for brachiopods from this locality. ${ }^{33,34,37}$ During serial sectioning of a specimen of this species (Fig. 4) the first indication of the internally "trapped" fossil appeared at $5.1 \mathrm{~mm}$ from the umbo (Fig. 4, F: 5.1; Table 2) as a cylindrical-elliptical shell section in the ventral (pedicular) valve. The maximum diameter of the unknown fossil in this first slice was $2.25 \mathrm{~mm}$ with a shell thickness of between 0.25 and $0.4 \mathrm{~mm}$. These dimensions already indicated that this fossil remain could not be a microfossil but a fragment(?) of a macrofossil. Further sectioning revealed the internal structure of the oval shell inclusion (Fig. 4. from F: 5.1 to M: 6.5 and Fig. 5A) with a shell thickness of $1.4 \mathrm{~mm}$. The dimensions of the shell increased rapidly in this short distance from the initial section with a diameter of $2.25 \mathrm{~mm}$ to $4.5 \mathrm{~mm}$ along the longer and $3.5 \mathrm{~mm}$ along the shorter angle of its elliptic shape. The thickness of the shell wall became thinner and varies from 0.25 to $0.06 \mathrm{~mm}$ (Fig. 4. M: 6.5). The internal structure of the shell at this stage was characterized by an internally spiralled fabric that resembles to the columella of a gastropod. The oval structure opened at $1.6 \mathrm{~mm}$ height and rapidly lost its elliptical shape (Fig. 4. N: 6.7 to 0: 6.9). From this stage to disappearing point (Fig. 4. AK: 12.8) the shell maintained the same shape: a curved arch. Further serial sections revealed a diminishing shell remain of an animal that lived inside the brachiopod. Total length of the fossil was 7,05 $\mathrm{mm}$ (Fig 4, from F: 5.1 to AK: 12.8). Maximum width was $8.13 \mathrm{~mm}$ (at Fig. 4, Y: 8.95 and Fig. 5B) maximum height 
was $3.75 \mathrm{~mm}$ (at Fig. 4, N: 6.7). Thickness of the shell remained stable and varies between 0.1 to $0.4 \mathrm{~mm}$. Beyond this stage distortion and asymmetry of the crus disappeared and became again symmetric (Fig. $5 B)$.

The brachiopod and entombed fossil external shapes approximated with a sphere (for the brachiopod, $\mathrm{R}$ $=10 \mathrm{~mm}$ ) and a half-sphere (for the entombed fossil, $r=4 \mathrm{~mm}$ ). Using these estimated figures, the estimated volume of the brachiopod shell cavity was $4190 \mathrm{~mm}^{3}$, while for the entombed fossil it was 134 $\mathrm{mm}^{3}$. The entombed fossil may have thus occupied about $3.2 \%$ of the total brachiopod shell interior. To evaluate the hypothesis of a possible co-existence between the brachiopod and the entombed fossil, we examined the spatial relationships between the trapped fossil and the brachiopod. To this end, we generated 3D digital reconstructions from the digitized manual drawings (Figure 6; Supplementary Movie 1). The brachiopod valves, the brachiopod crura, and the entombed fossil were reconstructed as distinct surfaces to allow their independent display with different visual attributes. The dynamic interactive visualization of the 3D reconstructions under various orientations confirmed that the position of the fossil behind the crura was not compatible with the hypothesis that it had entered the brachiopod cavity at an adult stage (Figure 6AB). Views along various directions confirmed the correlation between the presence of the entombed fossil and the asymmetrical shape of the crura. Views from the antero-posterior brachiopod axis indeed showed the dorso-ventral extension of the crura was shorter on the left side of the brachiopod, where the entombed fossil was located, compared with the right side (Figure 6AC). Views from the ventro-dorsal axis showed the medio-lateral extension of the crura was shorter on the left side (Figure 6DE). The 3D reconstruction of the entombed fossil confirmed the presence of a columellar structure in the part of the fossil located closest to the brachiopod posterior end (Figure 6F-H).

\section{Discussion}

In geosciences, 3D reconstruction is generally based on the registration of equally-spaced serial sections followed by segmentation of the structures of interest, which is typically done by extracting isosurfaces from the reconstructed image volumes. ${ }^{25}$ This approach imposes a number of constraints that have to be satisfied in order to get reliable reconstruction results. The first constraint is that registration has to be performed once for all before segmentation. In our experience, however, it is frequent that registration errors manifest themselves only at the visualization stage. Correcting such errors requires a closed-loop pipeline, whereby registration and segmentation can be corrected based on visualization feedback. The second constraint is that the contrast at the boundary of the structures of interest has to be sufficiently large and constant to ensure they can be extracted based on a single intensity threshold. When this not the case, as in the present study, manual contouring followed by contour triangulation may be the only feasible option, which comes at the cost of an increased complexity compared with isosurface extraction when facing complex topological changes. The third constraint is that the serial sectioning has to be performed at a constant spacing. This in turn generally imposes a small spacing to ensure the recovery of details in some regions, even though some regions could be reconstructed using a larger spacing. The number of images to be registered and segmented can become very large. Here, we took advantage of the 
$3 \mathrm{D}$ reconstruction and modelling software Free-D, initially developed for neuroanatomy then cell biology studies ${ }^{26,27}$ to propose an alternative approach avoiding all these constraints. We show here how using Free-D allowed us to generate insightful 3D reconstructions from manual drawings of sections digitized at arbitrary and varying intervals.

Based on our data, we present evidence and deductions that support the former co-existence of animals that were fossilized together and some speculations on the nature and possible taxonomic relationships of the entombed fossil.

\section{Evidence for the co-existence}

Our interpretation of the co-existence of these animals rests on the observations that:

i. the entombed shell is situated along the left internal wall of the brachiopod, with its apex close to the umbo of the host; their direction of growth are the same

ii. maximum length, width and height of the entombed shell is far longer, wider and higher than the maximum gape of the brachiopod valves,

iii. dimensions of the entombed fossil shell are beyond the maximum gaped width of the brachiopod shells therefore the entombed fossil shell could not have drifted through the commissure of the gaped brachiopod either if it was alive or dead,

iv. the usually symmetric brachidium of the brachiopod is asymmetric being short on the side of the entombed (=left side),

v. the left crus of the brachiopod is shorter, distorted and bent on the side of the entombed fossil

The most convincing evidence for the co-existence of the brachiopod and the captive animal is based on the position, placement and shape of the brachiopod crura. The brachidium is a symmetrically developed structure during the ontogeny. ${ }^{40}$ All the observed asymmetric deviations of the brachidium may refer to an affection, malformations or deviations caused by internal or external factors. ${ }^{41}$ Internal (=crural) deformations may appear due to difficult trophic conditions ${ }^{42}$ that create asymmetry of the brachidium. ${ }^{43}$ But in most cases both external and internal asymmetry are caused by external factors. ${ }^{44}$ Internal asymmetric development with symmetric shell also occurs as described at Recent terebratellidinide brachiopods. ${ }^{45}$ Complete reduction of one lophophore arm is probably connected with directions of food flows ${ }^{43}$ and are not pathologic. But not in this case. All the observed asymmetric deviations on the crura of the present specimen may refer to a special process that locally and only partially affected the crura.

Close to the umbo of the brachiopod (Fig. 4, E: 4.9 to L: 6.3; Fig. 6DE) the left crura is even more developed than its right counterpart, however it is observable (Fig. 4, M: 6.5; Fig. 6AC) that the left brachidium is underdeveloped and shortened. Partial underdevelopment and slight deformation are also present in more posterior regions (Fig. 4, from P: 7.1 to T: 7.9; Fig. 6DE). The most obvious affection on development of the brachidium by the entombed animal is seen on Fig 4, stages from V: 8.3 to Y: 8.95. Here, in the close vicinity of shell of the entombed animal the left brachidium is deformed and bending 
from the entombed fossil toward the symmetry plane of the brachidium (Fig. 4, V: 8.3) and becomes significantly shorter on the side of the entombed fossil (see on Fig 4, W: 8.5, X: 8.7, and Y: 8.95). These local deformations and asymmetries observed on 2D slices are confirmed by the 3D reconstructions of the whole brachidium, where they appear even more pronounced than in 2D (Fig. 6ACDE). From the point where the width of the entombed shell starts to decrease, the asymmetry of the brachidium of the brachiopod diminishes (as from Fig. 4, AE: 10.05) until the last section with preserved brachidium (Fig. 4, AM: 13.8; see also Fig. 6DE).

\section{The way of entombment}

Filter feeding sessile marine animals such as brachiopods, should control incoming water currents in order to filter or prevent any particle or animal to get into their body cavities. This is linked to their anatomy: they need inhalant currents to respirate and filter food particles. ${ }^{46}$ There are many protective techniques for brachiopods to protect the internal part of their shells. ${ }^{47,48,49,50}$ Among passive protection devices is the shape of the commissure. Brachiopods and oysters tend to develop zig-zag deflections that function as protective devices ${ }^{51}$ helping the animal to maintain the same area for influx of sea water as it would without deflections, but significantly decreases the size of grains/eggs able to pass through the commissure. ${ }^{51}$ In our case, this kingenoid terebratellidine brachiopod did not develop a complicated, zigzag shaped commissure, therefore any external particle could have penetrated through its commissure more easily. Most probably foraminifers and sponge spicules drifted into these brachiopods via the inhalant current. ${ }^{36}$ It seems plausible that the animal fossilized inside drifted as an egg into the brachiopod shell.

Other possible ways that the animal got into the shell is by the drifting of a hatched embryo or by the crawling of a juvenile bottom dwelling animal. But brachiopods also have active protective systems as the setae that sense an invader and protect the commissure. This function is well known among living brachiopods, ${ }^{52}$ however among fossil brachiopods long setae were also present. ${ }^{23,53}$ It implies that brachiopods may remotely (in a sense of couple of centimetres) control their ambience and easily recognize any invader approaching their commissure early enough to close their valves and prevent the intrusion.

The alternative hypothesis that the fossilized animal specimen was emplaced inside the valves as a corpse seems improbable. An evidence is presented ${ }^{54}$ that some brachiopods will not open their valves after decay of adductor muscles; however, slightly gaped atrypid brachiopods from the Devonian of Arizona is known. ${ }^{55}$ Such gaping brachiopods may have provided shelter or food for active benthic organisms. ${ }^{1}$ In this case it is highly improbable that the shelly animal drifted as a corpse or an abandoned shell into the brachiopod shell because its total length $(7.45 \mathrm{~mm})$ and height $(3.75 \mathrm{~mm})$ are greater than the slot of the brachiopod's open commissure. The valves of Recent rhynchonelliform brachiopods stay together after the death of the animal which implies that the entombed fossil was not able to penetrate into the brachiopod even if it was dead. All the above detailed observations show only 
one plausible solution: the animal that left the fossilized shell inside the brachiopod entered into the body cavity of the living brachiopod as an egg, hatched and developed inside the brachiopod body cavity and left evidence for co-action between the host and the undesired guest.

\section{The possible animal whose shell fossilized inside the brachiopod}

This locality that has provided rich and atypically large-sized brachiopods also provided other faunal elements: ammonites, mainly lytoceratids, but some phylloceratids- and haploceratids also occur, ${ }^{8,10}$ echinoderms, ${ }^{38}$ crustacean microcoprolites, ${ }^{31,34,36}$ sponge spicules, ${ }^{10,36}$ and foraminifers. ${ }^{10,36}$ Bivalves are missing, and only 3 poorly preserved gastropod remains were collected being rare, but living constituents in this environment; it is plausible that their eggs/larvae may have drifted/crawled into the gaped shells of brachiopods. The average size of encapsulated and shelled veliger gastropod embryos is 742 - $942 \mu \mathrm{m},{ }^{56}$ therefore they could have easily drifted inside gapping brachiopod shells. The size of the hatched crawling gastropod embryos varies between $909-1205,{ }^{56}$ so they also may crawl inside or have drifted into the brachiopod shell. But crawling into a living brachiopod shell is not probable. Other kinds of gastropod eggs exhibit even smaller dimensions. Many different neogastropod eggs from a deep-sea hydrothermal vent distribute sizes between 100 to $440 \mu \mathrm{m} .{ }^{57}$ Although this locality is not a classical deep-sea fossil vent locality but belongs to the rare, shallow marine, sediment hosted hydrothermal vent group $\left(\mathrm{SHV}^{39}\right)$. A recent analogue to the Zengővárkony fossil environment is provided ${ }^{58}$ from the submarine hydrothermal vents of the Tyrrhenian Sea (Italy), which suggests that gastropods may have inhabited hydrothermally influenced environments and are the most probable candidates for the entombed fossil. There is another evidence supporting a gastropod: at the apical part of the entombed fossil, a columella-like internal structure is seen on 2D and even 3D reconstructions (Fig. 6). There is evidence for the co-action between the gastropod and the brachiopod. The gastropod influenced the development of the crura of the brachiopod during ontogeny, which became shorter and deviated on the side where the gastropod lived.

\section{Conclusions}

This is the first fossil evidence that vagile animals may have lived encapsulated within another organism valves for a long time, until death. This is not purposeful parasitism but a genuine co-existence caused by coincidence. Most probably a gastropod fertilized egg drifted into the body cavity of the brachiopod, hatched there and started to grow in intimate proximity to the host animal. Evidence of the co-existence is based on the crural development of the brachiopod, the placement of the gastropod shell, and its dimensions.

This is the first successful attempt to apply a 3D modelling software initially designed for neurosciences and cell biology in the field of geosciences. It has potential to offer a wide range of applications in the geological- and other natural sciences. The rotatable virtual model of Free-D software helps to understand more thoroughly the intimate relationships between the host and the trapped animal shell, 
which is also a new approach in palaeontology and a novel technique that have not been used in geosciences before.

This research is a novel application of a 3D software designed for completely different purposes and helped to understand a unique kind of fossil, which preserved the first proven co-existence and co-action of a vagile animal that lived inside a sessile one in a Cretaceous sea 132 million year ago.

\section{Declarations}

\section{Acknowledgements}

The first of the authors (LB) acknowledge the financial support of the Bolyai János Research Grant of the Hungarian Academy of Sciences that financed the field work in 2010 [grant number 484/10]; and indebted to Attila Vörös (Hungary) for co-working on brachiopods from this locality. Fruitful comments on the nature of the entombed fossil with Franz Fürsich (Germany) is highly appreciated. The authors are indebted to Michael Sandy (USA) for the thorough discussions, comments and linguistic emendations of the draft that greatly improved the quality of the paper. The IJPB benefits from the support of Saclay Plant Sciences-SPS (ANR-17-EUR-0007).

Funding. The first of the authors (LB) acknowledge the financial support of the Bolyai János Research Grant of the Hungarian Academy of Sciences that financed the field work in 2010 [grant number 484/10]

Conflict of interest. The authors declare no competing financial interests.

Author contribution. L.B. made the field work, prepared the fossils, performed serial grinding, prepared 2D section drawings, and designed the study. Both authors wrote the manuscript. P.A. prepared the digital data, designed the 3D model, reconstruction and movie. All authors participated in discussion, interpretation, and confirmed the final version of the manuscript.

\section{References}

1. Brett, C. E. Entombment of a trilobite within a closed brachiopod shell. Journal of Paleontology 51(5), 1041-1045 (1977).

2. Zong, R-W., Fan, R-Y. \& Gong, Y-M. 2016, Seven 365-million-year-old trilobites moulting within a nautiloid conch. Scientific Reports 6, 34914. https://doi.org/10.1038/srep34914 (2016)

3. Fatka, O. \& Budil, P. Sheltered gregarious behaviour of Middle Ordovician Harpetid trilobites. Palaios 29(9), 495-500 (2014). https://doi.org/10.2110/palo.2013.031 (2014)

4. Fatka, O. \& Kozák, V. A new type of entombment of Peronopsis (Agnostida) in a hyolithid conch. Carnets de Géologie 14(10), 191-198. https://doi.org/10.4267/2042/54000 (2014)

5. Vörös, A. Fossilization of small ammonites in Brachiopoda valves. Földtani Közlöny 100(4), 399401. (1970). 
6. Detre, Cs. Tiny brachiopods and gastropods within brachiopod valves. Földtani Közlöny 103(2), 202-204 (1973).

7. Mironenko, A. A hermit crab preserved inside an ammonite shell from the Upper Jurassic of central Russia: Implications to ammonoid palaeoecology. Palaeogeography, Palaeoclimatology, Palaeoecology 537, 109397. https://doi.org/10.1016/j.palaeo.2019.109397 (2020)

8. Bujtor, L. The Early Valanginian ammonite, brachiopod and crustacean fauna of the Mecsek Mts. and its relationships with the embryonic shallow water hydrothermal vent at Zengővárkony (Mecsek Mts., South Hungary). Cretaceous Research 32, 565-574. https://doi.org/10.1016/j.cretres.2011.01.003 (2011)

9. Graziano, R., Buono, G. \& Taddei Ruggiero, E. Lower Toarcian (Jurassic) brachiopod-rich carbonate facies of the Gran Sasso range (central Apennines, Italy). Bollettino della Societá Paleontologica Italiana 45(1), 61-74. (2006)

10. Bujtor, L. \& Nagy, J. Fauna, palaeoecology and ecotypes of the Early Cretaceous sediment hosted hydrothermal vent environment of Zengővárkony (Mecsek Mountains, Hungary). Palaeogeography, Palaeoclimatology, Palaeoecology 564, 110179. https://doi.org/10.1016/j.palaeo.2020.110179 (2021)

11. Biernat, G. Diorygma atrypophilia n. gen., n. sp. - a parasitic organism of Atrypa zonata Schnur. Acta Palaeontologica Polonica 6(1), 17-28. (1961)

12. Chatterton, B.D.E. A commensal relationship between a small filter feeding organism and Australian Devonian spiriferid brachiopods. Paleobiology 1,371-378. (1975)

13. Zhang, Z., Strotz, L.C., Topper, T.P., Chen, F., Chen, Y., Liang, Y, Zhang, Z., Skovsted, C.B., Brock, G.A. An encrusting kleptoparasite-host interaction from the early Cambrian. Nature Communications 11, 2625. https://doi.org/10.1038/s41467-020-16332-3 (2020)

14. Schemm-Gregory, M. \& Sutton, M. First report of brachiopod-brachiopod endoparasitism. Lethaia 43, 112-115. https://doi.org/10.1111/j.1502-3931.2009.00177.x (2010)

15. Lazar, I., Panaiotu, C.E., Grigore, D., Sandy, M.R. \& Peckmann, J. An unusual brachiopod assemblage in a Late Jurassic (Kimmeridgian) stromatactis mud-mound of the Eastern Carpathians (Haghimas Mountains), Romania. Facies 57, 627-647. https://doi.org/10.1007/s10347-010-0261-x (2011)

16. Sutton, M. D., Briggs, D. E. G., Siveter, David J. \& Siveter, Derek J. A soft-bodied lophophorate from the Silurian of England. Biology Letters 7, 146-149. https://doi.org/10.1098/rsbl.2010.0540 (2011)

17. Fenton, C.L. A parasitic brachiopod. Nautilus 46(2), 52-54. (1932)

18. Wiśniewska, M. Les Rhynchonellides du Jurassique supérieur de Pologne. Palaeontologia Polonica 2,1-72. (1932)

19. Croft, W. N. A parallel grinding instrument for the investigation of fossils by serial sections. Journal of Paleontology 24, 693-698. (1950)

20. Sandy, M. R. Preparation of serial sections. In Feldmann, R. M., Chapman, R. E., Hannibal, J. T. (Eds.) Paleotechniques. Paleontological Society Special Publication 4, 146-156. (1989) 
21. Feldman, H. R., Schemm-Gregory, M., Wilson, M. A., Ahmad, F. Talexirhynchia, a new rhynchonellid genus from the Jurassic Ethiopian Province of Jordan. Paläontologische Zeitschrift 89(1), 25-35. https://doi.org/10.1007/s12542-013-0216-y (2015)

22. Sutton, M. D, Briggs, D. E. G., Siveter, David J. \& Siveter, Derek J. 2001. Methodologies for the visualization and reconstruction of three-dimensional fossils from the Silurian Herefordshire Lagerstätte. Paleontologia Electronica 4(1), art. 2, 17. http://palaeoelectronica.org/2001_1/s2/issue1_01.htm (2001)

23. Sutton, M. D., Briggs, D. E. G., Siveter, David J. \& Siveter, Derek J. Silurian brachiopods with soft-tissue preservation. Nature 436, 1013-1015. https://doi.org/10.1038/nature03846 (2005)

24. Bujtor, L. \& Vörös, A. New kingenoid (Terebratellidina) brachiopods with larger body sizes from the Early Cretaceous of Zengővárkony (Mecsek Mountains, Hungary). Journal of Paleontology 94(3), 475-488. https://doi.org/10.1017/jpa.2019.94 (2020)

25. Andrey, P. \& Maurin, Y. Free-D: an integrated environment for three-dimensional reconstruction from serial sections. Journal of Neuroscience Methods 145, 233-244 (2005).

26. Biot, E., Crowell, E., Burguet, J., Höfte, H., Vernhettes, S., \& Andrey, P. Strategy and software for the statistical spatial analysis of 3D intracellular distributions. Plant Journa/ 87, 230-242. (2016)

27. Burguet, J., Mailly, P., Maurin, Y. \& Andrey, P. Reconstructing the three-dimensional surface of a branching and merging biological structure from a stack of coplanar contours. Eighth IEEE International Symposium on Biomedical Imaging (ISBI 2011): From Nano to Macro, pp. 602-605. (2011)

28. Molnár, J. A zengővárkonyi vasérckutatás. Bányászati Lapok 94, 187-194. (1961)

29. Sztrókay, K. I. Mecseki vasércképződés. Magyar Tudományos Akadémia Mǔszaki Osztályának Közleményei 3, 11-23. (1952)

30. Pantó, G., Varrók, K. \& Kopek, G. A zengővárkonyi vasérckutatás földtani eredményei: Földtani Közlöny 85, 125-144. (1955)

31. Palik, P. Remains of crustacean excrement from the Lower Cretaceous of Hungary: Micropaleontology 11, 98-104. (1965)

32. Hetényi R., G. Hámor, I., \& Nagy, I. Magyarázó a Mecsek hegység földtani térképéhez. 10,000-es sorozat. Apátvarasd (Magyar Állami Földtani Intézet, Budapest, 1968).

33. Bujtor, L. Early Valanginian brachiopods from the Mecsek Mts (southern Hungary) and their paleobiogeographical significance: Neues Jahrbuch für Geologie und Paläontologie, Abhandlungen 241, 111-152. https://doi.org/10.1127/njgpa/241/2006/111 (2006)

34. Bujtor, L. A unique Valanginian paleoenvironment at an iron-ore deposit near Zengővárkony (Mecsek Mts., South Hungary) and a possible genetic model. Central European Geology 50, 183-198. https://doi.org/10.1556/CEuGeol.50.2007.3.1 (2007)

35. Bujtor, L., Janssen, N. M. M. \& Verreussel, R. Early Cretaceous (Valanginian and Hauterivian) belemnites and organic-walled dinoflagellate cysts from a marine hydrothermal vent site and 
adjacent facies in the Mecsek Mts., Hungary. Neues Jahrbuch für Geologie und Paläontologie 269(2), 135-148. https://doi.org/10.1127/0077-7749/2013/0341 (2013)

36. Bujtor, L. \& Szinger, B. Micropaleontological observations on the Lower Cretaceous iron ore-related formations of the Mecsek Mts. (Upper Valanginian - Lower Hauterivian, South Hungary). Central European Geology 61(2), 136-159. https://doi.org/10.1556/24.61.2018.08 (2018)

37. Vörös, A., Bujtor, L. Early Cretaceous brachiopods from a hydrothermally influenced environment of the Mecsek Mountains (Zengővárkony, southern Hungary) and their palaeobiogeographical relationships. Cretaceous Research 114, 104497. https://doi.org/10.1016/j.cretres.2020.104497 (2020)

38. Bujtor, L. Cretaceous echinoid (Plegiocidaris) from the Mecsek Mts, Hungary. Földtani Közlöny 143(4), 321-326. (2013)

39. Bell, J. B., Woulds, C., Brown, L. E., Sweeting, C. J., Reid, W. D. K., Little, C. T. S. \& Glover, A. G. Macrofaunal ecology of sedimented hydrothermal vents in the Bransfield Strait, Antarctica. Frontiers Marine Sciences, 3(32), 1-16. https://doi.org/10.3389/fmars.2016.00032 (2016)

40. López Carranza, N. \& Carlson, S.J. Testing Species Assignments in Extant Terebratulide Brachiopods: A Three-dimensional Geometric Morphometric Analysis of Long-Looped Brachidia. PLoS ONE 14(11), e0225528. https://doi.org/10.1371/journal.pone.0225528 (2019)

41. Afanasjeva, G.A. Asymmetry in Brachiopods. Paleontological Journal 48(11), 1207-1214. https://doi.org/10.1134/S0031030114110033 (2012)

42. Copper, P. Morphology and distribution of Kerpina Struve (Devonian Atrypida), Paläontologische Zeitschrift 41(1/2), 73-85. (1967)

43. Madison, A.A. Formation of cardinal process in Ordovician Strophomenids. Paleontological Journal 46(12), 1362-1374. https://doi.org/10.1134/S0031030112120039 (2012)

44. Usnarska-Talerzak, K. Morphology and postembryonic development of Coenothyris vulgaris (Schlotheim) brachiopoda Middle Triassic. Acta Palaeontologica Polonica 33(2), 169-202. (1988)

45. Atkins, D. A new species and genus of Brachiopoda from the western approaches, and the growth stages of the lophophore. Journal of the Marine Biological Association of the United Kingdom 39, 71-89. https://doi.org/10.1017/S0025315400013114 (1960)

46. Atkins, D. The ciliary feeding mechanism of the Megathyridae (Brachiopoda), and the growth stages of the lophophore. Journal of the Marine Biological Association of the United Kingdom 39, 459-479. https://doi.org/10.1017/S0025315400013485 (1960)

47. Alexander, R.R. Mechanical strength of shells of selected extant articulated brachiopods: implications for Paleozoic morphologic trends. Historical Biology 3, 169-188. https://doi.org/10.1080/08912969009386520 (1990)

48. Brunton, C.H.C. Shut tightly and protected. Brachiopods through Time, MacKinnon, D.I., Lee, D.E. and Campbell, J.D. (Eds.) A.A. Balkema, Rotterdam, The Netherlands, 197-200. (1991)

49. Peck, L. S. The tissues of articulate brachiopods and their value to predators. Philosophical Transactions of the Royal Society B: Biological Sciences 339 (1287), 17-32. 
https://doi.org/10.1098/rstb.1993.0002 (1993)

50. Seidel, R. \& Lüter, C. Overcoming the fragility - X-ray computed micro-tomography elucidates brachiopod endoskeletons. Frontiers in Zoology 11, 65. https://doi.org/10.1186/s12983-014-0065-x (2014)

51. Rudwick, M. J. S. The function of zigzag deflexions in the commissures of fossil brachiopods. Palaeontology 7(1), 135-171. (1964)

52. LaBarbera, M. Mechanisms of spatial competition of Discinisca strigata (Inarticulata: Brachiopoda) in the intertidal of Panama. Biological Bulletin 168, 91-105. (1985)

53. Topper, T. P., Strotz, L. C., Holmer, L. E., Zhang, Z., Tait, N. N. \& Caron, J.-B. Competition and mimicry: the curious case of chaetae in brachiopods from the middle Cambrian Burgess Shale: $B M C$ Evolutionary Biology. https://doi.org/10.1186/s12862-015-0314-4 (2015)

54. Thayer, C.W. Diductor muscles of brachiopods: active or passive? Paleobiology 1(1), 44-47. (1975)

55. Teichert, C. Devonian rocks and paleogeography of Central Arizona. USGS Professional Papers 464, 1-181. (1965)

56. Pechenik, J. A. Egg capsules of Nucella lapillus (L.) protect against low-salinity stress. Journal of Experimental Marine Biology and Ecology 71, 165-179. (1983)

57. Gustafson, R.G., Littlewood, D.T.J. \& Lutz, R.A. Gastropod egg capsules and their contents from deepsea hydrothermal vent environments. Biological Bulletin 180, 34-55. (1991)

58. Ferretti, A., Messori, F., Di Bella, M., Sabatino, G., Quartieri, S., Cavalazzi, B., Italiano, F., Barbieri, R. Armoured sponge spicules from Panarea Island (Italy): Implications for their fossil preservation. Palaeogeography, Palaeoclimatology, Palaeoecology 536, 109379 https://doi.org/10.1016/j.palaeo.2019.109379 (2019)

\section{Tables}

Table 1 Dimensions of the serial sectioned specimen. L: length; W: width; T: thickness.

\begin{tabular}{|lllll|}
\hline specimen & L & W & T & length of crura \\
\hline PAL 2019.7.1 & 22.6 & 18.9 & 15.2 & 13.1 \\
\hline
\end{tabular}

Due to technical limitations, table 2 is only available as a download in the Supplemental Files section.

\section{Figures}




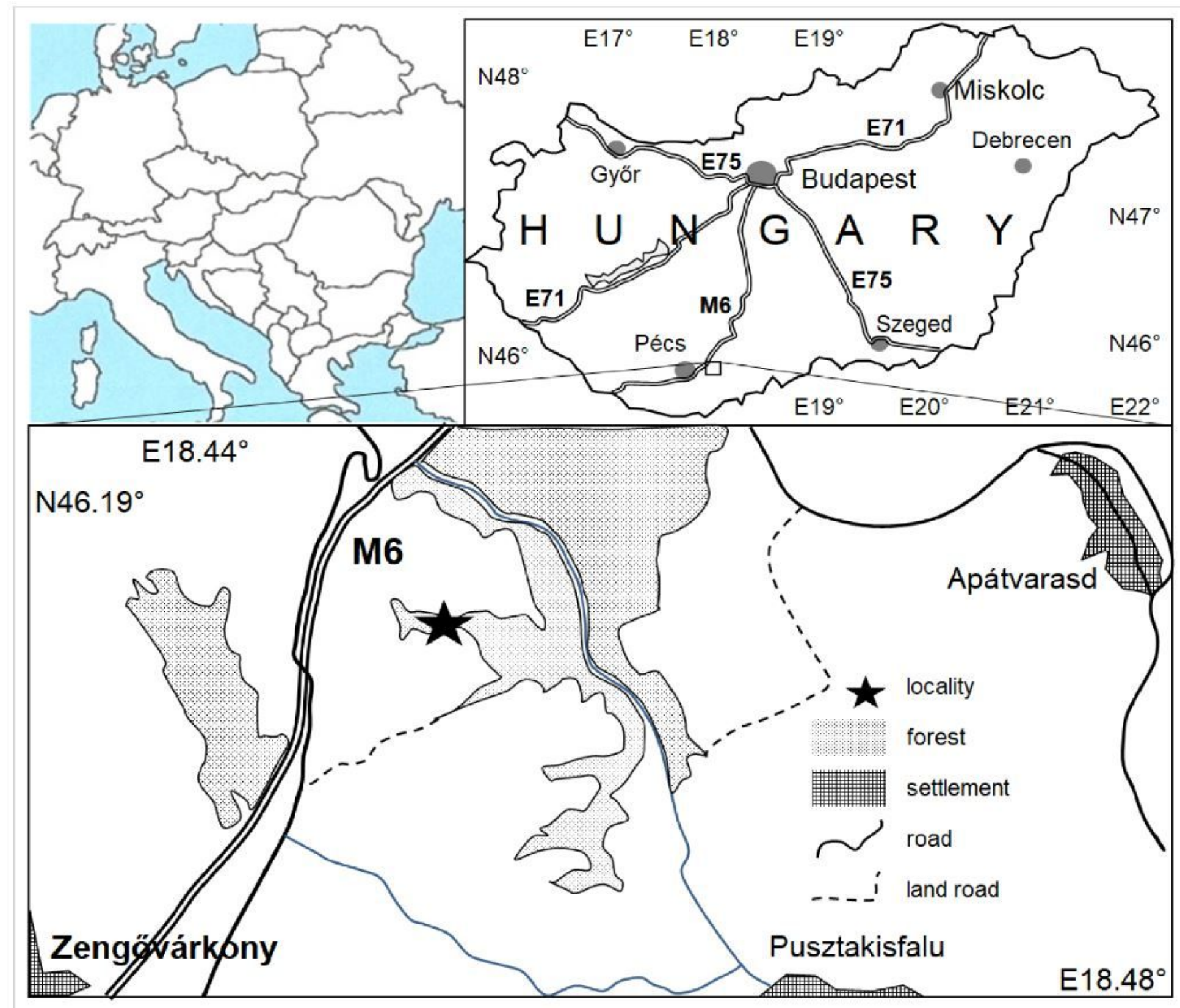

Figure 1

Locality map. Simplified map of Hungary with black square indicating the study area. Asterisk indicates the locality. Note: The designations employed and the presentation of the material on this map do not imply the expression of any opinion whatsoever on the part of Research Square concerning the legal status of any country, territory, city or area or of its authorities, or concerning the delimitation of its frontiers or boundaries. This map has been provided by the authors. 


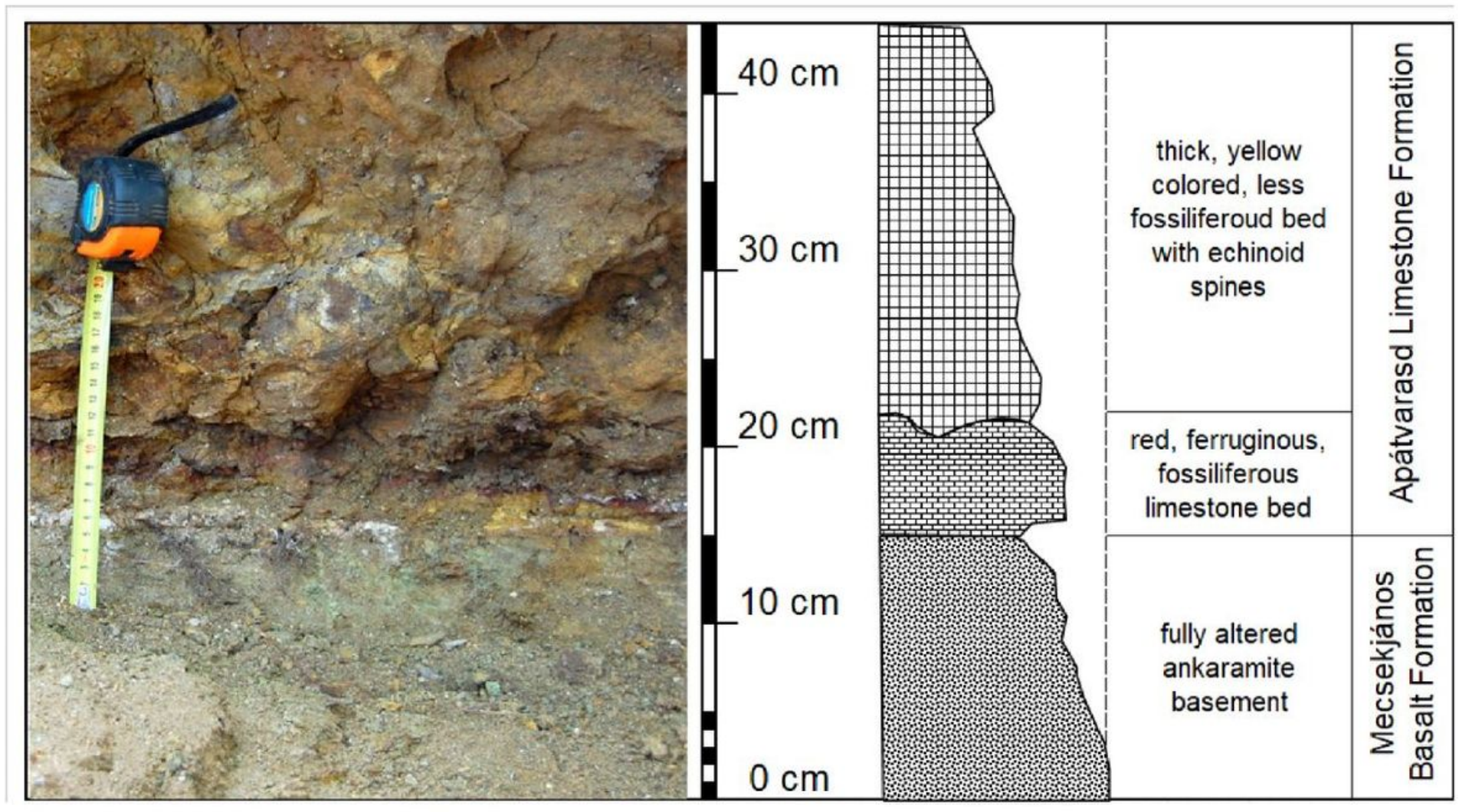

Figure 2

The upper Valanginian-lower Hauterivian section at Zengővárkony traversing the Mecsekjánosi Basalt Fm and the Apátvarasd Limestone Fm after Bujtor $(2006,2007)$ and Bujtor and Vörös $(2020)$ simplified. Coordinates: $46.18545^{\circ} \mathrm{N}, 18.45299^{\circ} \mathrm{E}$. Note: The designations employed and the presentation of the material on this map do not imply the expression of any opinion whatsoever on the part of Research Square concerning the legal status of any country, territory, city or area or of its authorities, or concerning the delimitation of its frontiers or boundaries. This map has been provided by the authors. 


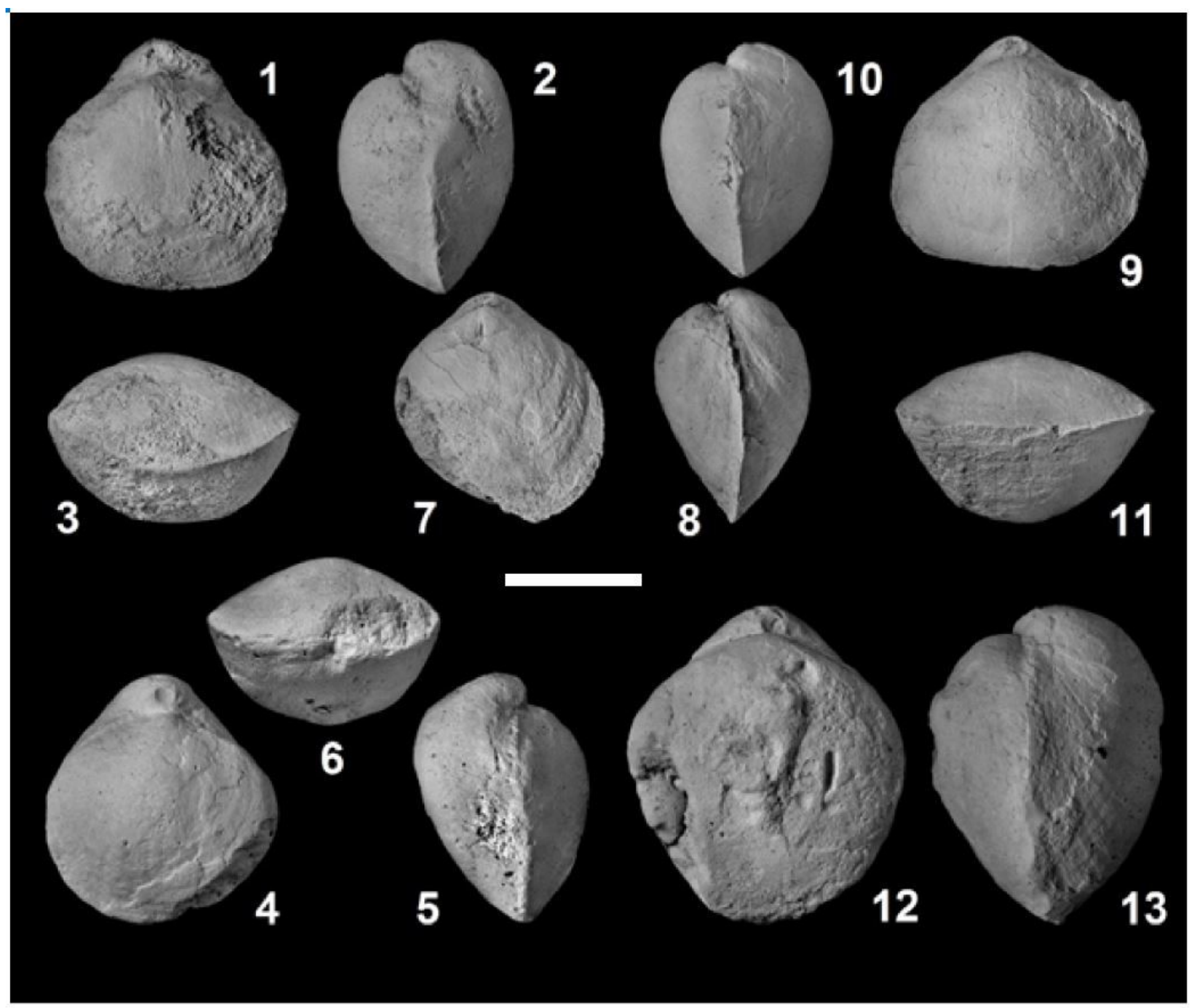

\section{Figure 3}

Zittelina hofmanni Bujtor and Vörös, 2020. Paratype (PAL 2019.5.1) refigured after Fig. 6.12, 6.13 of Bujtor and Vörös (2020). 

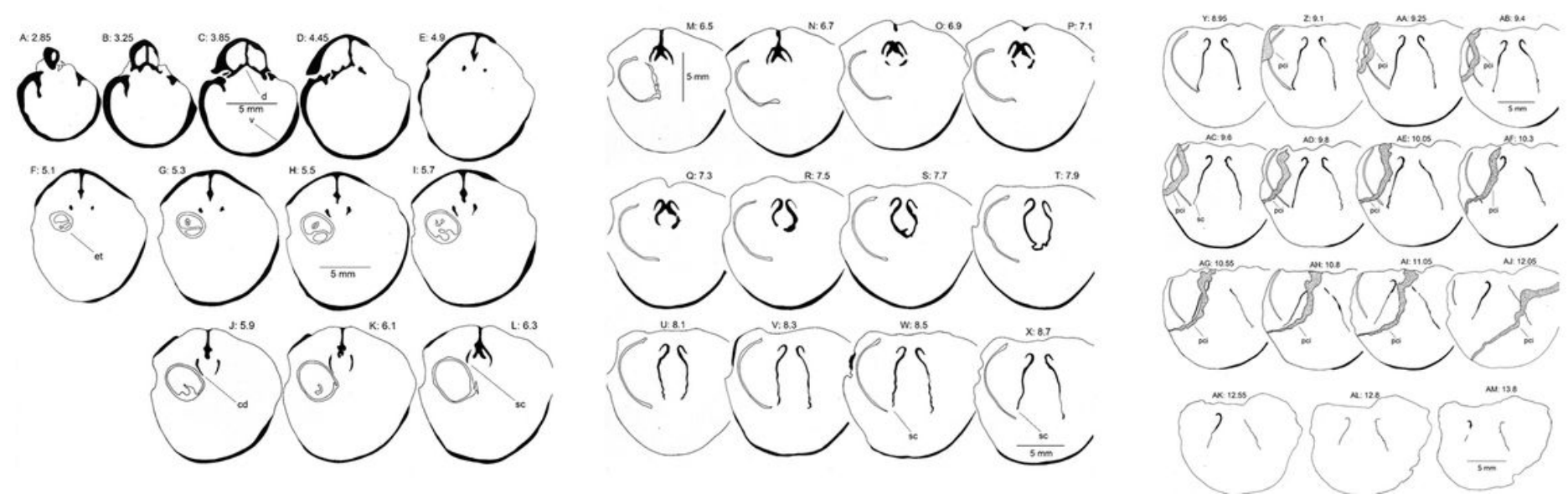

\section{Figure 4}

Serial section drawings from a specimen of Zittelina hofmanni Bujtor and Vörös, 2020 number PAL 2019.7.1 with indication of the brachiopod internal structures and the entombed fossil remain.

Abbreviations: cd: crura deformed; d: dorsal valve; et: entombed fossil; pci: post-depositional calcite vein; sc: shortened crura; v: ventral valve. In order to distinguish the differences between the brachiopod shell and the entombed fossil, brachiopod shell is shaded in black, while the shell of the entombed fossil is left white. Scale bar indicates $500 \mu \mathrm{m}$.
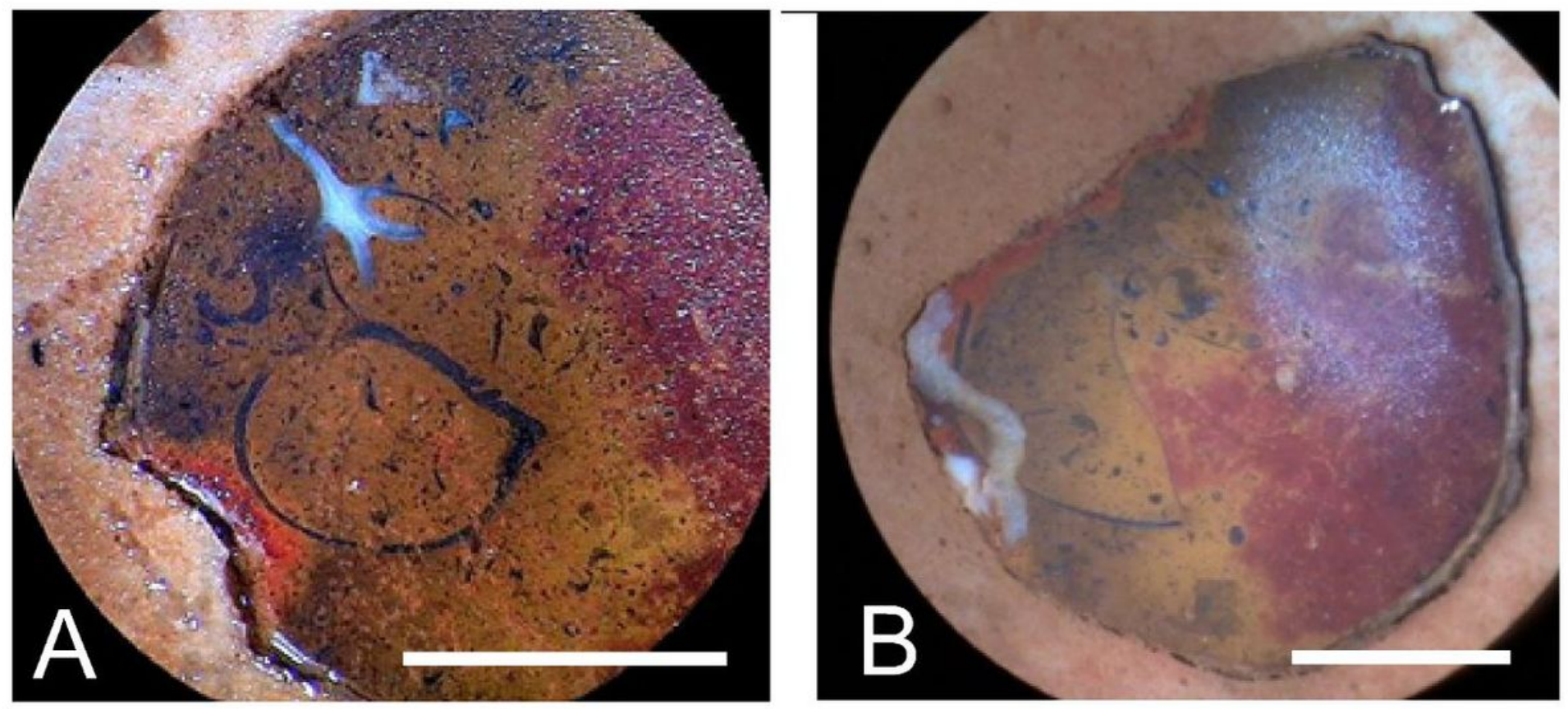

\section{Figure 5}

Photographs of two serial sections from Fig. 4. Pictures were taken incidentally by a Samsung Xcover 271 mobile phone 2MP rear side camera; A) Corresponds to Fig. 4, section M: 6.5; Light blue coloured anatomical part is the crura of the brachiopod; B) Corresponds to Fig. 4, section AA: 9.25. White coloured 
stripe on the left is a post-depositional calcite vein penetrated through the valve during diagenesis. Scale bars indicate $5 \mathrm{~mm}$.

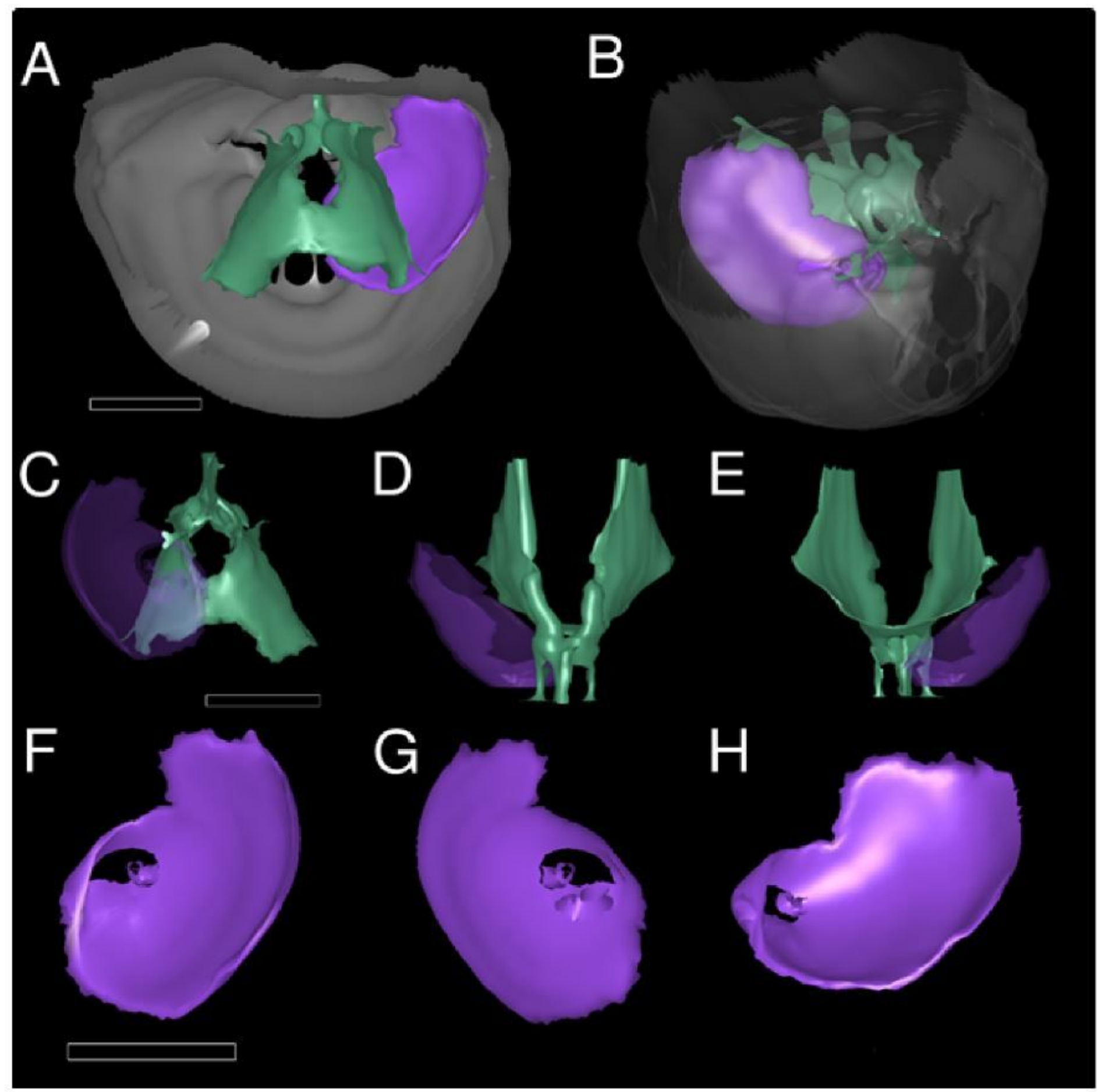

\section{Figure 6}

3D modelling of the gastropod shell inside the brachiopod valves. AB. Brachiopod valves (opaque and transparent grey), brachiopod crura (magenta), and gastropod shell (green) seen from the front of the brachiopod (A) or in arbitrary orientation (B). CDE. Gastropod shell displayed as a transparent surface together with brachiopod crura. Views are from rear (C), top (D) and bottom (E) of the brachiopod. FGH. 
Close-up views of the supposed gastropod shell. Views are from front $(F)$ and rear $(G)$ of the brachiopod, or in arbitrary orientation $(\mathrm{H})$. 3D scale bar: $5 \mathrm{~mm}$.

\section{Supplementary Files}

This is a list of supplementary files associated with this preprint. Click to download.

- BujtorLAndreyPSUPPFinal.xIsx

- Table2.jpg

- BujtorLAndreyPLifeSentsupplementmovie1.mp4 